\title{
A Comparison between Characterization and Biological Properties of Brazilian Fresh and Aged Propolis
}

\author{
Eduardo Morgado Schmidt, ${ }^{1,2}$ Daniele Stock, ${ }^{1}$ \\ Fabio José Garcia Chada, ${ }^{3}$ Daiane Finger, ${ }^{1}$ Alexandra Christine Helena Frankland Sawaya, ${ }^{4}$ \\ Marcos Nogueira Eberlin, ${ }^{2}$ Maria Lurdes Felsner, ${ }^{1}$ Sueli Pércio Quináia, \\ Marta Chagas Monteiro, ${ }^{3}$ and Yohandra Reyes Torres ${ }^{1}$ \\ ${ }^{1}$ Departamento de Química, Universidade Estadual do Centro Oeste (UNICENTRO), CEDETEG, \\ Rua Simeão Camargo Varela de Sá, 03 Vila Carli, 85040-080 Guarapuava, PR, Brazil \\ ${ }^{2}$ Laboratório Thomson de Espectrometria de Massas, Departamento de Química Analítica, \\ Instituto de Química, Universidade Estadual de Campinas (UNICAMP), 13083-970 Campinas, SP, Brazil \\ ${ }^{3}$ Programa de Pós-Graduação em Ciências Farmacêuticas, Faculdade de Farmácia, Universidade Federal do Pará (UFPA), \\ Avenida Augusto Correa No. 1, 66075-110 Belém, PA, Brazil \\ ${ }^{4}$ Departamento de Fisiologia Vegetal, Instituto de Biologia, Universidade Estadual de Campinas, 13083-970 Campinas, SP, Brazil
}

Correspondence should be addressed to Marta Chagas Monteiro; martachagas2@yahoo.com.br

Received 15 July 2014; Revised 29 August 2014; Accepted 2 September 2014; Published 3 November 2014

Academic Editor: Adair Santos

Copyright ( 2014 Eduardo Morgado Schmidt et al. This is an open access article distributed under the Creative Commons Attribution License, which permits unrestricted use, distribution, and reproduction in any medium, provided the original work is properly cited.

Objective. As propolis is a highly valued bee product, we aimed to verify the quality of aged propolis, investigating their phenolic and flavonoid composition, levels of toxic metals, radical scavenging and antimicrobial activities. Material and Methods. Samples of fresh and aged propolis of six different beekeepers, from the same geographical location, were investigated in terms of their phenolic and flavonoid composition and levels of $\mathrm{Pb}, \mathrm{Cd}$, and $\mathrm{Cr}$, as well as radical scavenging and antimicrobial activities. Results. The two groups of propolis had similar qualitative composition by HPLC-PDA and ESI(-)-MS. Fresh propolis and aged propolis show no differences when average values of extraction yield, flavonoids, $\mathrm{EC}_{50}$, or MIC were compared and both types of propolis showed good antimicrobial activity at low concentrations. Only levels of phenolic compounds were higher in fresh propolis. Conclusion. The propolis samples considered in this study, aged or fresh, had similar qualitative composition, although they were collected in different periods. Samples only differed in their levels of total phenolic content. Moreover, aged propolis conserves significant radical scavenging and antimicrobial properties. We suggest that aged propolis should not be discarded but explored for alternative applications.

\section{Introduction}

Propolis is a resinous hive substance containing beeswax, plant exudates, and salivary secretions from bees. Extracts of propolis are used as phytochemical ingredient in functional foods at levels that may confer health benefits $[1,2]$. The smell, color, constitution, and composition of propolis greatly vary as a function of the different botanical sources available around the hive and the geographical and climatic conditions $[3,4]$ but also depend on the method of harvest [5].
Flavonoids and phenolic acids or their esters often form up to $50 \%$ of all propolis constituents [6]. Several biological activities, such as antibacterial $[7,8]$, antiviral $[7,9]$, antioxidant $[10,11]$, anti-inflammatory $[12,13]$, anticancer [14-16], and antifungal $[17,18]$ properties, have been reported for propolis and as a result this resin is a highly valued bee product.

Brazilian propolis is appreciated worldwide. From 2010 to 2012 the price of a kilogram of raw Brazilian propolis increased more than $50 \%$ in the international market. 


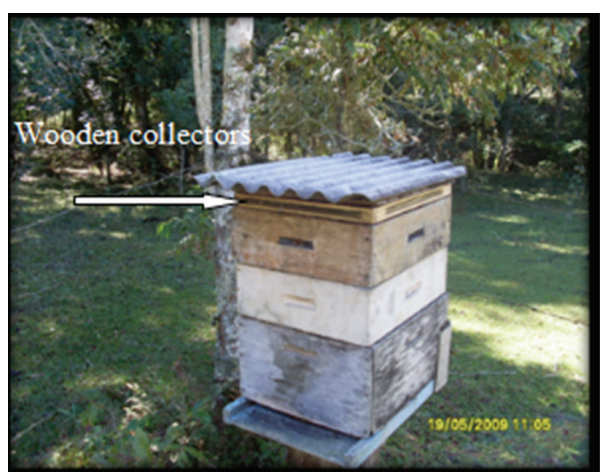

(a)

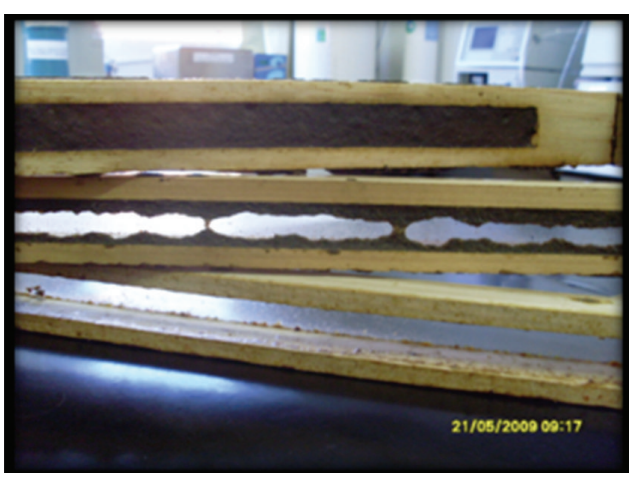

(b)

FIGURE 1: Wooden collectors of propolis (a) placed in the hive to collect fresh propolis and (b) in the lab after 42 days sealed with fresh propolis.

According to data from the Japan Trade Organization, 92\% of raw propolis consumed in Japan is from Brazil. Propolis which remains long periods in hives (aged propolis) has a dry consistency and is usually discarded by beekeepers. In this study we aimed to verify the quality of aged propolis. Therefore, samples of fresh and aged propolis from six different beekeepers but from the same geographical location were investigated in terms of their phenolic and flavonoid composition and levels of metals, as well as radical scavenging and antimicrobial activities.

\section{Materials and Methods}

2.1. Propolis Samples. Propolis samples from honeybees (Apis mellifera) were collected from hives of six different beekeepers from Prudentópolis, Paraná State, Brazil. On April 7th, 2009, the propolis samples considered as aged (M) (because they had remained in hives for at least 180 days) were collected (1st collection). By the occasion of this collection, wooden collectors were placed in hives to promote the production of fresh propolis (F) (Figure 1). The set of propolis samples considered as fresh propolis were gathered from the wooden collectors on May 19th, 2009 (2nd collection), 42 days after the first collection.

2.2. Extracts. Ground propolis ( $5 \mathrm{~g}$ ) from both the 1 st and 2nd collection was extracted with $50 \mathrm{~mL}$ of a $70 \% \mathrm{v} / \mathrm{v}$ hydroalcoholic solution. After stirring in shaker at room temperature for $100 \mathrm{~h}$, these solutions were filtered. The ethanolic solvent was removed under reduced pressure yielding ethanolic extracts of propolis identified as aged propolis $\mathrm{M}$ (1st collection) and fresh propolis $\mathrm{F}$ (2nd collection).

\subsection{HPLC Analysis with a Photodiode Array Detector (HPLC-} $P D A)$. The chromatographic profiles of the different propolis extracts were determined by HPLC (Waters 600) with photodiode array detector operating in a $1 \mathrm{D}$ detection mode at $292 \mathrm{~nm}$. A thermostatized $\left(30 \pm 1^{\circ} \mathrm{C}\right) \mu$ Bondapak C-18 analytical column $(3.9 \times 300 \mathrm{~mm}, 10 \mu \mathrm{m})$ was used. A binary mobile phase of acetonitrile and $0.5 \%$ of aqueous formic acid was employed at an elution rate of $1 \mathrm{~mL} \mathrm{~min}^{-1}$. Linear gradient was performed starting with $30 \%$ of acetonitrile to $100 \%$ for $30 \mathrm{~min}$. All propolis extract solutions were prepared in acetonitrile at $1000 \mu \mathrm{g} \mathrm{mL}^{-1}$ and $5 \mu \mathrm{L}$ and were injected through a loop system.

2.4. ESI(-)-MS Fingerprints and LC-MS Analysis. Firstly, propolis extracts were analyzed by ESI(-)-MS to obtain representative fingerprints and compare their qualitative profiles [19]. Analyses were carried out in a Q-Trap Mass Spectrometer (Applied Biosystems) with direct infusion into the electrospray ionization interface operating in the negative ion mode. Capillary and cone voltages were set to $-3000 \mathrm{~V}$ and $-50 \mathrm{~V}$, respectively. Nitrogen was used as nebulizing and desolvation gas. Desolvation temperature was $100^{\circ} \mathrm{C}$.

Subsequently, extracts were introduced into an HPLC (Agillent) with a Waters $\mu$ Bondapak C18 analytical column $(3.9 \times 300 \mathrm{~mm}, 10 \mu \mathrm{m})$ and detected in a Triple Quadruple API-5000 mass analyzer. Electrospray ionization was carried out with capillary and cone voltages set to $-4000 \mathrm{~V}$ and $-70 \mathrm{~V}$, respectively. Desolvation temperature was $150^{\circ} \mathrm{C}$ and nitrogen was used as collision gas. A binary mobile phase of methanol and $1 \%$ of aqueous formic acid was employed at an elution rate of $1 \mathrm{~mL} \mathrm{~min}^{-1}$. Elution started with $40 \%$ of methanol in $1 \%$ of aqueous formic acid for $25 \mathrm{~min}$. After that period, a linear gradient was performed for $30 \mathrm{~min}$ until $100 \%$ methanol. The chromatographic system was allowed to equilibrate for $5 \mathrm{~min}$ between injections.

2.5. Total Phenolic Content. The amount of total phenolic components was determined by the Folin-Ciocalteau method with some modifications $[15,20,21]$. Solutions of propolis extracts were prepared in methanol at a concentration of $1000 \mu \mathrm{g} \mathrm{mL}^{-1}$. In a $5 \mathrm{~mL}$ volumetric flask, $500 \mu \mathrm{L}$ of a buffer solution $(20 \mathrm{~g}$ sodium carbonate and $1.2 \mathrm{~g}$ sodium potassium tartrate in $100 \mathrm{~mL}$ of water), $500 \mu \mathrm{L}$ of FolinCiocalteau reagent (Biotec, $2 \mathrm{~mol} \mathrm{~L}^{-1}$ ), and $300 \mu \mathrm{L}$ of the analytical standard or propolis extract solution were mixed and the volume was completed with ultrapure water (PKA Genpure). Absorbance was measured in a Varian Cary 50 Bio 
UV-Vis spectrophotometer at $760 \mathrm{~nm}$ after $30 \mathrm{~min}$ at room temperature. The calibration curve was set up by measuring the absorbance of the commercial gallic acid (Vetec, 99\%) standard solutions ranging from 10 to $280 \mu \mathrm{g} \mathrm{mL}^{-1}$. The total phenolic content was expressed in mg of gallic acid per $\mathrm{g}$ of propolis extract.

2.6. Flavonoid Content. The amount of total flavonoids was determined by the method that employs dihydrate aluminum chloride in methanol $[15,21]$. Solutions containing propolis extracts at $1000 \mu \mathrm{g} \mathrm{mL}^{-1}$ were prepared in methanol. In a $5 \mathrm{~mL}$ volumetric flask, $500 \mu \mathrm{L}$ of each analytical solution (standard or propolis extracts) and $250 \mu \mathrm{L}$ of aluminum chloride methanolic solution $(5 \% \mathrm{w} / \mathrm{v})$ were mixed and diluted with methanol. After $30 \mathrm{~min}$ absorbance was measured at $425 \mathrm{~nm}$ in a Varian Cary 50 Bio UV-Vis spectrophotometer. Quercetin (Sigma, 98\%) was employed as analytical standard in concentrations ranging from 1 to $50 \mu \mathrm{g} \mathrm{mL}^{-1}$ and the results were expressed as $\mathrm{mg}$ of quercetin per $\mathrm{g}$ of propolis extract.

2.7. Determination of Levels of Metals. Levels of Cd, Cr, and $\mathrm{Pb}$ were evaluated in propolis extracts by atomic absorption spectrophotometry (FAAS). A Varian AA-220 atomic absorption spectrometer equipped with a deuterium-arc lamp background corrector was used. $\mathrm{Cd}, \mathrm{Cr}$, and $\mathrm{Pb}$ were analyzed in an air-acetylene flame. Samples of $0.025 \mathrm{~g}$ of each propolis extract (in triplicate) were dissolved in methanol in a $25 \mathrm{~mL}$ volumetric flask. Aliquots from these solutions were directly aspirated into the FAAS. The same procedure was performed with metal standard solutions in methanol. The burner height and the flow rates of sample and acetylene were adjusted in order to obtain the maximum absorbance signal.

2.8. Radical Scavenging Activity. The radical scavenging activity was determined by the DPPH test. A stock solution of DPPH $\left(1.6 \times 10^{-3} \mathrm{~mol} \mathrm{~L}^{-1}\right)$ was made in ethanol and filtered through Milli Q. The working DPPH ethanolic solutions (8.0 $\times 10^{-5} \mathrm{~mol} \mathrm{~L}^{-1}$ ) were prepared directly in a plastic cuvette for every measurement. All solutions of propolis extracts were prepared in ethanol at a concentration of $1000 \mu \mathrm{g} \mathrm{mL}^{-1}$ and different aliquots were removed from these solutions to construct the analytical curve. The mixture of DPPH and antioxidants in increasing concentrations was left to stand for $30 \mathrm{~min}$ at room temperature in the dark and then absorbance was measured at $515 \mathrm{~nm}$. Antiradical activity of the extracts was expressed as $\mathrm{EC}_{50}$, meaning the concentration of propolis extract that reduced in $50 \%$ the absorbance of the working DPPH ethanolic solutions at the initial concentration of $8.0 \times$ $10^{-5} \mathrm{~mol} \mathrm{~L}^{-1}$. To calculate $\mathrm{EC}_{50}$ an analytical curve for antiradical activity $(\%)$ versus extract concentration $\left(\mu \mathrm{g} \mathrm{mL}^{-1}\right)$ was plotted. The radical scavenging activity was calculated according to the following formula:

$$
\% \text { Antiradical activity }=100 \times \frac{\left(\mathrm{Abs}_{i}-\mathrm{Abs}_{f}\right)}{\mathrm{Abs}_{i}}
$$

where $\mathrm{Abs}_{i}$ is absorbance of working DPPH ethanolic solutions, $t=0$, and $\mathrm{Abs}_{f}$ is absorbance of $\mathrm{DPPH}$ ethanolic solutions containing different concentrations of antioxidants, $t=30 \mathrm{~min}$.

2.9. In Vitro Antimicrobial Activity. Antibacterial activity was evaluated for the following standard strains: (i) Grampositive bacteria, Staphylococcus aureus (ATCC 6538), Enterococcus faecalis (ATCC 29212), and Micrococcus luteus (ATCC), and (ii) Gram-negative bacteria, Pseudomonas aeruginosa (ATCC 25853) and Escherichia coli (ATCC 8739). All strains were obtained from the INCQS/FIOCRUZ (National Institute for Health Quality Control, Brazil). The microorganisms used in the study were maintained in the Laboratory of Microbiology at College of Pharmacy, Federal University of Pará, UFPA. The standard strains were kept in nutrient agar at room temperature. For the tests, all strains were grown in Petri dishes containing a specific media for each bacterium: mannitol salt agar medium to grow $S$. aureus; nutrient agar for E. faecalis; cetrimide agar for P. aeruginosa, and MacConkey Agar for E. coli. Plates were incubated at $37^{\circ} \mathrm{C}$ for $24 \mathrm{~h}$ to induce the exponential growth after lag time.

For bacterial inoculum preparation, strains were grown to exponential phase in Mueller-Hinton broth (Merck, Germany) at $37^{\circ} \mathrm{C}$ for $24 \mathrm{~h}$ and adjusted by diluting fresh cultures to turbidity equivalent to $0.5 \mathrm{McF}$ arland scale (approximately $2 \times 10^{8} \mathrm{CFU} \mathrm{mL}^{-1}$ ) and then diluted until $1 \times 10^{3} \mathrm{CFU} \mathrm{mL}^{-1}$, as described by Clinical and Laboratory Standards Institute [22].

Minimum inhibitory concentration (MIC) and minimum bactericidal concentration (MBC) assays were performed by using the broth microdilution method in Mueller-Hinton broth (MHB) as described by CLSI [22]. MIC is defined as the lowest concentration of extract with no visible growth of the microorganism in the resazurin colorimetric assay. To determine MIC, fresh and aged propolis extract were dissolved in dimethylsulfoxide (DMSO) in the highest concentration $\left(8000 \mu \mathrm{g} \mathrm{mL}^{-1}\right)$ to be tested. A serial twofold dilution was made in a concentration range from 100 to $8000 \mu \mathrm{g} \mathrm{mL}^{-1}$ in $1 \mathrm{~mL}$ sterile test tubes containing MHB.

For the microdilution test, the inoculum $(100 \mu \mathrm{L})$ containing $5 \times 10^{3} \mathrm{CFU} \mathrm{mL} \mathrm{m}^{-1}$ was added to each well and $100 \mu \mathrm{L}$ from their serial dilutions was transferred into consecutive wells. After $24 \mathrm{~h}$ of incubation, $15 \mu \mathrm{L}$ of resazurin $\left(1 \mu \mathrm{g} \mathrm{mL}^{-1}\right)$, which is metabolically reduced by active cells to a colored derivative, was added to the wells to allow visual identification of metabolic activity [23]. After incubation, the development of a purple-pink color was considered as the indicative of bacterial growth. Therefore MIC was read as the lowest concentration of the extract where the purple-pink color was not observed. To determine $\mathrm{MBC}, 10 \mu \mathrm{L}$ of broth was taken from each well and incubated in Mueller Hinton Agar at $37^{\circ} \mathrm{C}$ for $24 \mathrm{~h}$ and for each bacterium. The MBC was defined as the lowest extract concentration that resulted in a colony count lower than three colonies per $\mathrm{mL}(99.9 \%$ killing) or no bacterial growth, as described by de Quadros et al. [24]. Each test was performed in three replicates. Negative control consisted of $100 \mu \mathrm{L}$ of the bacterial inoculum 
TABLE 1: Total phenolic, flavonoids, yields, and radical scavenging activity for extracts of aged (M) and fresh (F) propolis from beekeepers 1 to $6^{*}$.

\begin{tabular}{lcccc}
\hline Propolis & Yield (\%) & Total phenolic content $\left(\mathrm{mgg}^{-1}\right)$ & Total flavonoid content $\left(\mathrm{mg} \mathrm{g}^{-1}\right)$ & $\begin{array}{c}\mathrm{DPPH} \\
\left(\mu \mathrm{mL}^{-1}\right)\end{array}$ \\
\hline $1 \mathrm{M}$ & 67 & $108.9 \pm 3.2$ & $9.3 \pm 0.1$ & 49.88 \\
$1 \mathrm{~F}$ & 81 & $149.3 \pm 5.1$ & $6.7 \pm 0.4$ & 36.60 \\
$2 \mathrm{M}$ & 65 & $114.8 \pm 5.4$ & $14.0 \pm 0.4$ & 38.50 \\
$2 \mathrm{~F}$ & 85 & $147.4 \pm 4.1$ & $11.1 \pm 0.5$ & 35.65 \\
$3 \mathrm{M}$ & 64 & $120.5 \pm 3.6$ & $21.0 \pm 0.3$ & 27.52 \\
$3 \mathrm{~F}$ & 65 & $143.9 \pm 3.0$ & $20.9 \pm 0.9$ & 17.13 \\
$4 \mathrm{M}$ & 77 & $106.7 \pm 2.6$ & $16.5 \pm 1.2$ & 43.59 \\
$4 \mathrm{~F}$ & 70 & $121.8 \pm 0.8$ & $17.7 \pm 0.6$ & 36.52 \\
$5 \mathrm{M}$ & 53 & $99.9 \pm 1.8$ & $14.1 \pm 2.5$ & 50.83 \\
$5 \mathrm{~F}$ & 60 & $131.3 \pm 0.6$ & $9.1 \pm 0.2$ & 48.67 \\
$6 \mathrm{M}$ & 56 & $93.7 \pm 0.2$ & $10.6 \pm 0.3$ & 73.26 \\
$6 \mathrm{~F}$ & 62 & $101.9 \pm 4.2$ & $6.0 \pm 0.2$ & 83.60 \\
\hline $\mathrm{M}$ & $64 \pm 8$ & $107 \pm 10^{\mathrm{a}}$ & $14 \pm 4$ & $47 \pm 15$ \\
$\mathrm{~F}$ & $71 \pm 11$ & $133 \pm 18^{\mathrm{b}}$ & $12 \pm 6$ & $43 \pm 22$ \\
\hline
\end{tabular}

${ }^{*}$ Data are represented as average values \pm standard deviation. Different letter represents significant statistical differences $(P<0.05)$ between average values for aged and fresh propolis.

and $100 \mu \mathrm{L}$ of DMSO. Chloramphenicol $\left(250 \mu \mathrm{g} \mathrm{mL}^{-1}\right)$ and penicillin/streptomycin $\left(100 \mathrm{U} \mathrm{mL}^{-1}\right)$ were used as positive controls for Gram-positive and Gram-negative bacteria, respectively.

2.10. Statistical Analysis. The differences between average values of extraction yield, phenolic and flavonoid amounts, and also antiradical and antimicrobial activities, for aged and fresh propolis (two experimental groups), were investigated by a one-way ANOVA at $95 \%$ confidence level. To identify the average values which statistically differ from each other, a Tukey multiple comparisons mean test, at the same confidence level, was applied.

\section{Results}

3.1. Comparison of the Qualitative Profiles of Fresh and Aged Propolis Samples. According to beekeepers who provided samples for the current study, propolis from the 1st collection had not been harvested for at least 180 days and had a drier consistency and darker color than the fresh propolis samples. The 2 nd collection was carried out 42 days after the 1st collection. All propolis samples were extracted with ethanol $70 \%(\mathrm{v} / \mathrm{v})$. An aliquot of each extract was injected in HPLC and analyzed by HPLC-PDA and ESI(-)-MS. The analyses by HPLC-PDA and chromatograms detected at $292 \mathrm{~nm}$ showed that although propolis samples were obtained from different beekeepers and different periods (but from nearby areas) their chromatographic profiles were similar (Figure 2). However, propolis 3 and propolis 4 had higher concentration of major components, especially the peaks with $t_{R} 20$ and 22 minutes.

ESI(-)-MS fingerprints showed a complex chemical composition and ions of $\mathrm{m} / \mathrm{z} 299$ or $\mathrm{m} / \mathrm{z} 301$ were observed in the fingerprints of all samples (Figure 3). LC-MS analysis allowed the identification of several compounds which we have reported earlier in our studies with propolis from Prudentópolis (Paraná) [15, 16]. Dicaffeoylquinic acid isomers with $[\mathrm{M}-\mathrm{H}]^{-}$ions of $m / z 515$ but different retention times were detected. Ions of $m / z 163\left(t_{R} 7.2\right), m / z 231\left(t_{R}\right.$ 16.5), and $m / z 329\left(t_{R}\right.$ 19.8) were identified as the $[\mathrm{M}-\mathrm{H}]^{-}$ions of p-coumaric acid, 4-hydroxy-3-prenylcinnamic acid, and betuletol, respectively. Ions of $\mathrm{m} / \mathrm{z} 299$ were detected at two different retention times (17.2 and 21.6) and were attributed to kaempferide and 3,5-diprenyl-4-hydroxycinnamic acid (artepillin C). Similarly, ions of $\mathrm{m} / \mathrm{z} 301$ (at $12.8 \mathrm{~min}$ and $25.5 \mathrm{~min}$ ) were attributed to dihydrokaempferide and $E / Z$ communic acid, respectively.

3.2. Total Phenolic and Flavonoid Contents in Fresh and Aged Propolis. When extraction yield, total phenolic and flavonoid levels for aged and fresh propolis were compared in pairs for the same beekeeper, a trend toward higher amounts of extraction yield and total phenolic acids in fresh propolis is noticed (Table 1). Conversely, the amount of flavonoids was slightly superior in aged propolis, with the exception of propolis from beekeepers 3 and 4 for which no statistical differences were observed.

3.3. Radical Scavenging Activity by the DPPH Assay. The $\mathrm{DPPH}$ assay was performed for aged and fresh propolis obtained from different beekeepers in order to verify the effect that long periods in hive have on propolis radical scavenging activity (Table 1). All extracts obtained from fresh propolis had higher radical scavenging activity (lower $\mathrm{EC}_{50}$ value) than the extracts obtained from aged propolis from the same beekeeper, except for extracts $6 \mathrm{M}$ and $6 \mathrm{~F}$. 


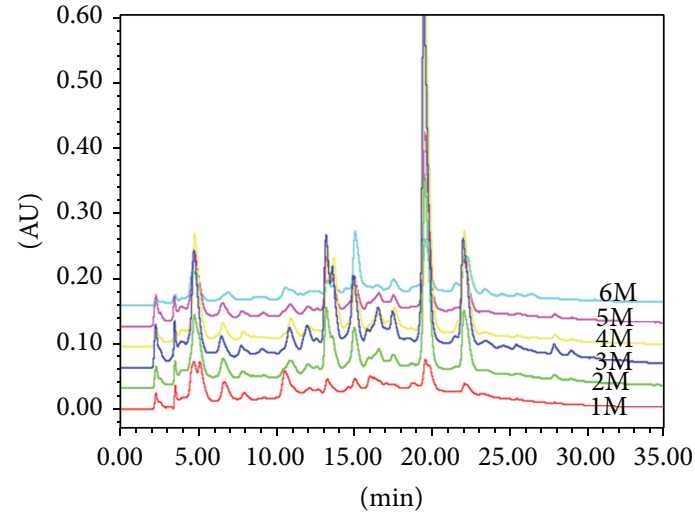

(a)

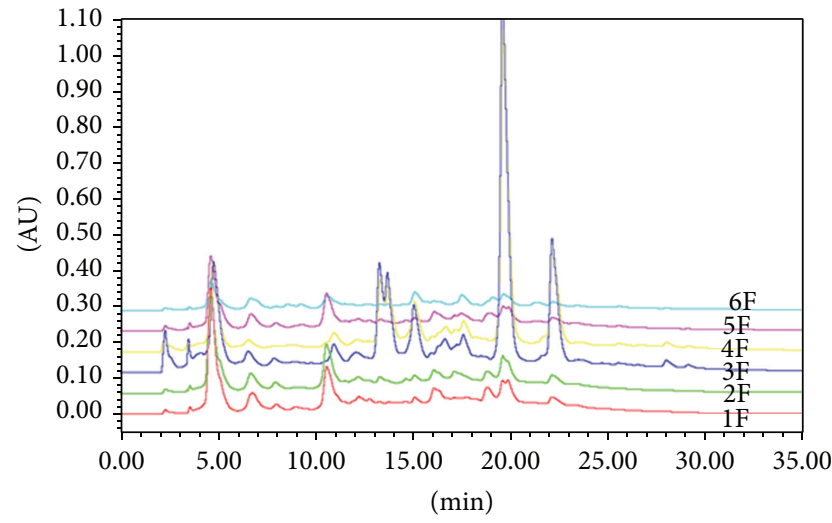

(b)

FIgURE 2: Chromatograms detected at $292 \mathrm{~nm}$ for propolis extracts from different beekeepers. (a) Aged propolis and (b) fresh propolis.

TABLE 2: Minimum inhibitory concentration (MIC) and minimum bactericidal concentration (MBC) for extracts of aged (M) and fresh (F) propolis from beekeepers 1 to 6 .

\begin{tabular}{|c|c|c|c|c|c|c|}
\hline \multirow{3}{*}{ Propolis } & \multicolumn{6}{|c|}{ Bacteria-MIC and $\mathrm{MBC}\left(\mu \mathrm{g} \mathrm{mL}^{-1}\right)$} \\
\hline & \multicolumn{2}{|c|}{ Staphylococcus aureus } & \multicolumn{2}{|c|}{ Enterococcus faecalis } & \multicolumn{2}{|c|}{ Micrococcus luteus } \\
\hline & MIC & $\mathrm{MBC}$ & MIC & $\mathrm{MBC}$ & MIC & $\mathrm{MBC}$ \\
\hline $1 \mathrm{M}$ & 1300 & 2600 & 2600 & $>5190$ & 650 & 1300 \\
\hline $1 \mathrm{~F}$ & 400 & 1620 & 810 & 1620 & 400 & 810 \\
\hline $2 \mathrm{M}$ & 560 & 780 & 1560 & 3110 & 390 & 1560 \\
\hline $2 \mathrm{~F}$ & 360 & 680 & 2730 & 5450 & 680 & 1360 \\
\hline $3 \mathrm{M}$ & 340 & 680 & 2720 & 2720 & 340 & 680 \\
\hline $3 \mathrm{~F}$ & 380 & 380 & 1500 & 1500 & 380 & 750 \\
\hline $4 \mathrm{M}$ & 340 & 670 & 1340 & 2680 & 340 & 1340 \\
\hline $4 \mathrm{~F}$ & 380 & 380 & 770 & 3100 & 380 & 770 \\
\hline $5 \mathrm{M}$ & 690 & 690 & 1370 & 5480 & 340 & 690 \\
\hline $5 \mathrm{~F}$ & 390 & 770 & 1540 & $>3090$ & 390 & 1540 \\
\hline $6 \mathrm{M}$ & 670 & 670 & 1340 & 2680 & 340 & 670 \\
\hline $6 \mathrm{~F}$ & 380 & 760 & 760 & 3070 & 380 & 380 \\
\hline M & $650 \pm 353$ & $1015 \pm 777$ & $1822 \pm 621$ & $3643 \pm 1324$ & $400 \pm 124$ & $1040 \pm 404$ \\
\hline $\mathrm{F}$ & $382^{*} \pm 13$ & $765 \pm 455$ & $1352 \pm 767$ & $2972 \pm 1427$ & $435 \pm 120$ & $935 \pm 432$ \\
\hline
\end{tabular}

${ }^{*}$ Data are represented as average values \pm standard deviation $(P<0.05)$.

3.4. Antimicrobial Activity. The in vitro antibacterial activity was assessed through the values of MIC and MBC of six aged $(\mathrm{M})$ and six fresh $(\mathrm{F})$ propolis samples against strains of Gram-positive and Gram-negative bacteria. Table 2 shows that all extracts, regardless of being from aged or from fresh propolis, were able to inhibit the growth of Grampositive bacteria, mainly $S$. aureus and $M$. luteus, at low concentrations showing a good antimicrobial activity. These propolis extracts were however not effective against Gramnegative bacteria, with MIC values higher than $4000 \mu \mathrm{g} \mathrm{mL}^{-1}$ (data not shown).

3.5. Statistical Analysis. To statistically compare aged and fresh propolis samples, they were considered as two experimental groups and the quantitative data obtained were analyzed by a one-way ANOVA. No statistical difference at the 95\% confidence level was observed between average values of (i) extraction yield (aged propolis: $64 \pm 8 \%$, fresh propolis: $71 \pm 11 \%$ ); (ii) flavonoids levels (aged propolis: $14 \pm 4 \mathrm{mgg}^{-1}$, fresh propolis: $12 \pm 6 \mathrm{mg} \mathrm{g}^{-1}$ ), and (iii) $\mathrm{EC}_{50}$ in DPPH test (aged propolis: $47 \pm 15 \mu \mathrm{g} \mathrm{mL}^{-1}$, fresh propolis: $43 \pm 22 \mu \mathrm{g} \mathrm{mL}^{-1}$ ), considering the six beekeepers altogether. The same result was obtained when MIC and MBC mean values for each bacterium were statistically compared: (i) Staphylococcus aureus (aged propolis: MIC $650 \pm 353 \mu \mathrm{g} \mathrm{mL}^{-1}$ and MBC $1015 \pm 777 \mu \mathrm{g} \mathrm{mL}^{-1}$, fresh propolis: MIC $382 \pm$ $13 \mu \mathrm{g} \mathrm{mL}^{-1}$ and MBC $765 \pm 455 \mu \mathrm{g} \mathrm{mL}^{-1}$ ); (ii) Enterococcus faecalis (aged propolis: MIC $1822 \pm 656 \mu \mathrm{g} \mathrm{mL}^{-1}$ and MBC $3643 \pm 1324 \mu \mathrm{g} \mathrm{mL}^{-1}$, fresh propolis: MIC $1352 \pm 767 \mu \mathrm{g} \mathrm{mL}^{-1}$ and MBC $2972 \pm 1427 \mu \mathrm{g} \mathrm{mL}^{-1}$ ); Micrococcus luteus (aged 
propolis: MIC $400 \pm 124 \mu \mathrm{g} \mathrm{mL}^{-1}$ and MBC $1040 \pm 404 \mu \mathrm{g} / \mathrm{mL}$, fresh propolis: MIC $435 \pm 120 \mu \mathrm{g} \mathrm{mL}^{-1}$ and MBC $935 \pm$ $\left.432 \mu \mathrm{g} \mathrm{mL}^{-1}\right)$. For Gram-negative strains, the antibacterial activity was weak for both fresh and aged propolis. Extracts of propolis are extensively described as being effective against Gram-positive bacteria but very weak against Gram-negative ones $[15,25]$. Aged and fresh propolis had however mean phenolic values which statistically differ at the $95 \%$ confidence level with a trend to fresh propolis showing higher levels $\left(133 \pm 18 \mathrm{mg} \mathrm{g}^{-1}\right)$ than the aged samples $\left(107 \pm 10 \mathrm{mg} \mathrm{g}^{-1}\right)$.

\section{Discussions}

The main purpose of the current study was to verify if propolis which remains for long period in hives is of lower quality, considering important parameters such as total phenolic and flavonoid contents, radical scavenging and antimicrobial activities, and levels of toxic metals. Aged propolis was compared to fresh propolis from the same geographical area.

The qualitative chemical profile observed by HPLC-PDA, ESI(-)-MS and LC-MS for all samples was alike despite aged and fresh propolis having been collected in different periods and from different beekeepers (Figures 2 and 3). Consequently, it was assumed that the qualitative composition of these propolis samples was not significantly affected by seasonal effects. As aged and fresh propolis had similar ions in their fingerprint it can be deduced that bees used the same plant sources to collect the resin. The vegetal origin of propolis from Paraná State is complex and Baccharis dracunculifolia, Araucaria heterophylla and Araucaria angustifolia have been suggested as possible plant sources [19, 26, 27]. Park et al. [28] reported based on physicochemical characteristics that the main botanical origin of propolis from southeastern Brazil was Baccharis dracunculifolia DC. (Compositae), popularly known as "alecrim-do-campo," which is largely distributed in South America from southeastern Brazil to Argentina and Uruguay. Propolis from B. dracunculifolia is rich in phenolic acids, particularly prenylated derivatives of p-coumaric acid, as shown in our data.

Among tropical countries, Brazil has the widest chemical diversity of propolis types; however variations in qualitative chemical composition of Brazilian propolis due to seasonal effect are not always observed. In this regard, SimõesAmbrosio et al. [29] evaluated the role of seasonality on the inhibitory effect on the oxidative metabolism of neutrophils of Brazilian green propolis collected monthly from November 2001 to October 2002 . The authors verified that the HPLC qualitative profiles of the extracts were very similar. Nonetheless, there was wide variation in the quantitative profile which resulted in significant differences in the inhibitory effects of the propolis samples during the studied period. The same way, Teixeira et al. [30] observed that most compounds of a sample of Brazilian propolis (from Minas Gerais State) were detected throughout a year but their contents varied along the year. Additionally, the lack of seasonal effects on the antimicrobial activity against Staphylococcus aureus and Escherichia coli $[25]$ and against Candida albicans $[17,18]$ and on the immunomodulatory action [31] of propolis collected from the same geographical region in São Paulo State, Brazil, in four seasons throughout a whole year was reported.

The amounts of phenolic and flavonoid constituents vary widely according to propolis types and seasonal factors $[30,32,33]$. Moreover, some studies reported that the phenolic content is related to the various pharmacological activities reported for propolis, such as antibacterial, antiinflammatory, hepatoprotective, and antioxidant activities $[34,35]$. In this study, the only variable which statistically differed between aged and fresh propolis was the total phenolic content; however these differences in content did not reduce significantly the radical scavenging and antimicrobial activities of the aged propolis. Several studies showed that propolis from tropical regions contains a diversity of phenolics, such as prenylated cinnamic acid derivatives, flavonoids, polyprenylated benzophenones, and other classes of constituents $[7,18,36]$. In a previous study, we identified several prenylated phenolic acids in an extract of propolis obtained with edible vegetable oil (ODEP) such as 3,4-dihydroxy-5-prenyl-cinnamic acid, 3-prenyl-4-hydroxycinnamic acid, and (E)-3-\{4-hydroxy-3[(E)-4-(2,3-dihydrocinnamoy-loxy)-3-methyl-2-butenyl]-5prenyl-phenyl\}-2-propenoic acid [18]. This oil extract was obtained from a propolis sample collected in Prudentopolis, Paraná State (the same area as the samples in this study). ODEP showed antifungal activity against several strains of Candida albicans [18]. Recently, we also reported that this extract exerted hyperlocomotor and anxiolytic- and antidepressant-like effects in the CNS in different animal models, as well as antioxidant activity after stress induced by the forced swim test [37].

The potent antioxidant activity of Brazilian propolis observed in our study was also shown by Guimarães et al. [38] who tested propolis collected from Brazil with strong DPPH free radical scavenging activity (ED50 values around $45.43 \mu \mathrm{g} / \mathrm{mL}$ ). In this regard, Banskota et al. [39] reported that the antioxidative activity of propolis is due to its phenolic constituents, which also possess antitumour and antihepatotoxic activities. These compounds may reduce intracellular peroxides levels, such as ROS, which acts as second messengers for signal transduction pathways that regulate cell proliferation and are associated with tumour promotion and induction of the carcinogenesis.

Concerning the antimicrobial activity, when fresh and aged propolis are pair-compared for the same beekeeper slightly better radical scavenging and antimicrobial activities were found for fresh propolis which showed a good antimicrobial activity mainly against $S$. aureus. Nevertheless, when these activities are compared considering all the fresh samples and all the aged samples, no statistical differences between average values were observed. Others studies also reported that propolis is active mainly against Gram-positive bacteria but shows a limited activity against Gram-negative bacteria [40-43]. These variations in the susceptibility to propolis among several microorganisms have been reported, but their mechanisms of action are poorly disclosed. Then, the mechanism of antimicrobial activity of propolis is complex and is attributed to a synergism between phenolic and other compounds in the resin [44]. Though, some studies suggested 


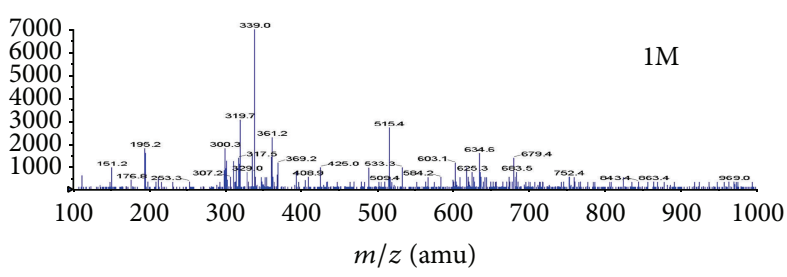

(a)

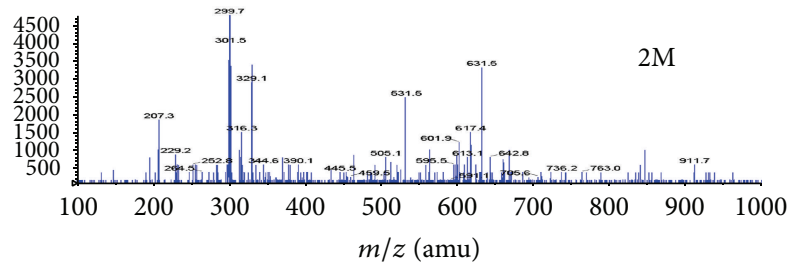

(c)

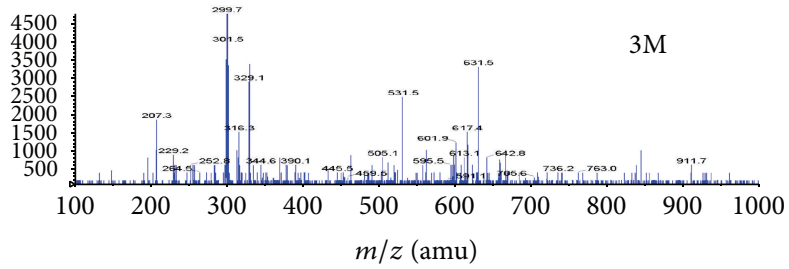

(e)

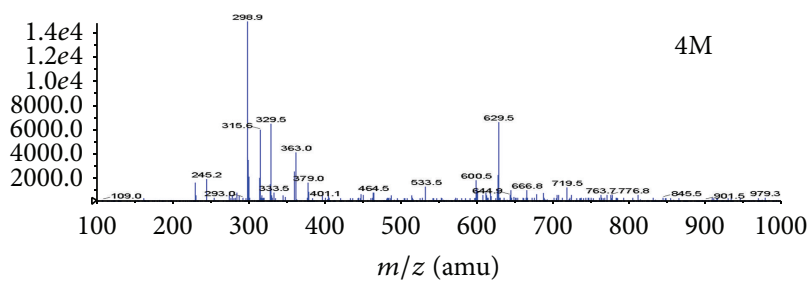

(g)

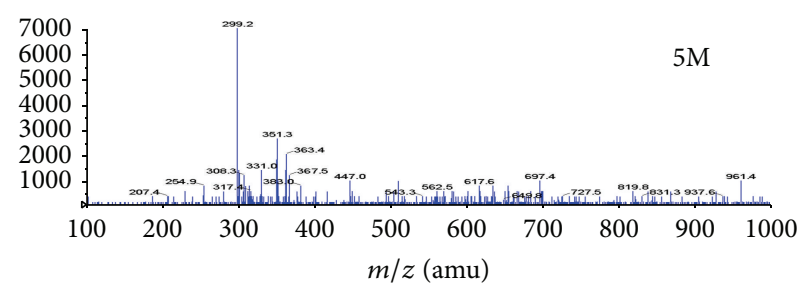

(i)

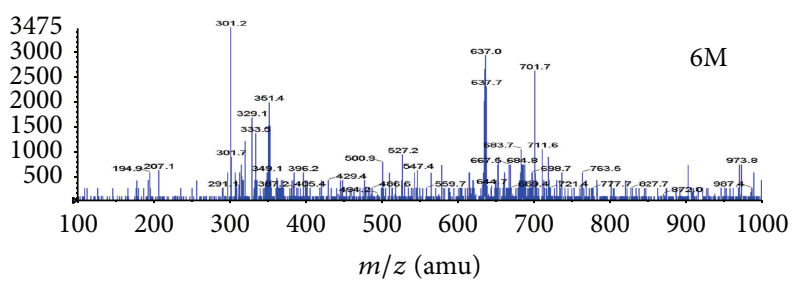

(k)

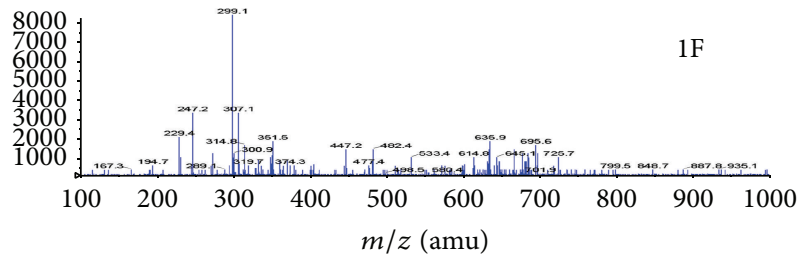

(b)

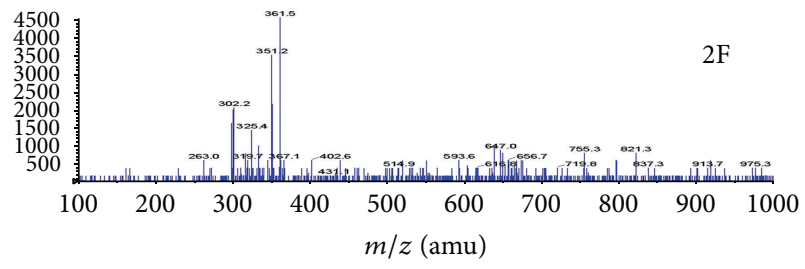

(d)

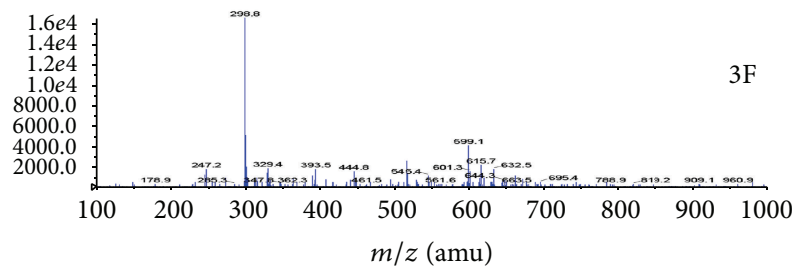

(f)

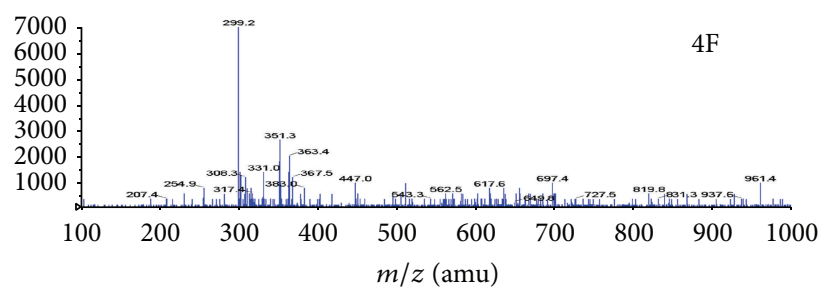

(h)

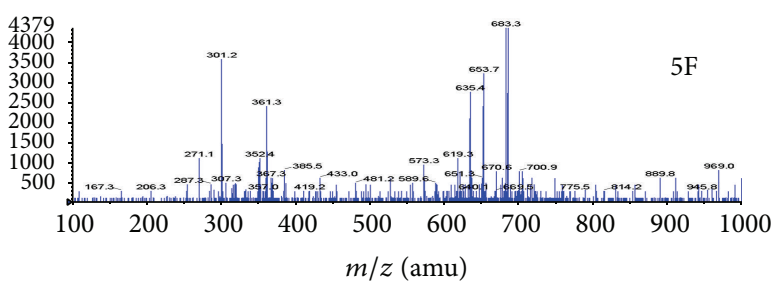

(j)

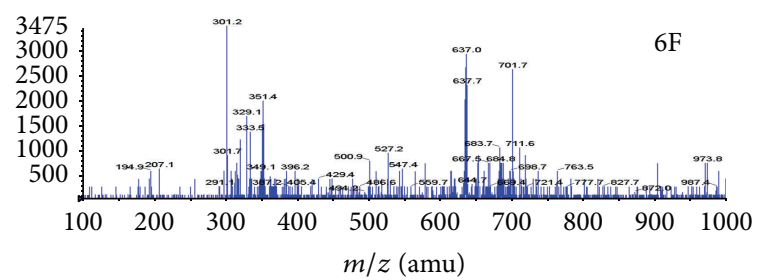

(l)

FIgURE 3: ESI(-)-MS fingerprints for aged (M) and fresh (F) propolis extracts from different beekeepers.

that propolis and some of its components had an antibacterial effect due to damage to the cytoplasmic membrane of bacteria and so increasing its permeability providing the leakage of the important intracellular solute potassium [39, 45-47]. In addition, Mirzoeva et al. [45] reported that propolis and some of its components altered ionic permeability of the bacterial inner membrane leading to dissipation of the membrane potential due to the electrochemical gradient of protons across the membrane. This is essential to maintain ATP synthesis, membrane transport, and motility of the 
bacteria. In this regard, Cushnie and Lamb [46] showed that galangin, an important component of propolis, may induce potassium loss producing damage on cytoplasmic membrane, weakening the cell wall, or the inhibition of its synthesis and thereby resulting in osmotic lysis.

Finally, it is also important to highlight that toxic elements such as $\mathrm{Pb}, \mathrm{Cd}$, and $\mathrm{Cr}$ were not detected in fresh or aged propolis extracts. The presence of these metals in propolis has been attributed to environmental contamination of air, plants, soil, or waters around the hives due to anthropic activities [48]. $\mathrm{Pb}, \mathrm{Cd}$, and $\mathrm{Cr}$ were below detection limits in extracts from aged and fresh propolis despite the fact that aged propolis remained more time in hives and were accumulated in hives during a more extended period than fresh propolis, being more exposed to environmental conditions. In Brazil, the Ministry of Agriculture, Livestock and SupplyMAPA-approved a technical protocol to define the identity of bee products and minimal parameters for their quality control [49]. In this protocol a minimum amount of $0.25 \%$ $(\mathrm{w} / \mathrm{w})$ of flavonoids and $0.50 \%(\mathrm{w} / \mathrm{w})$ for phenolics in extracts of propolis extracts is established. It also states that inorganic contaminants must not be present in propolis or extracts in higher amounts than those defined by the specific regulation for honeys. Currently, MAPA has implemented "The National Plan for Control of Residues and Contaminants in Products of Animal Origin" (PNCRC/ANIMAL) as a tool to ensure quality throughout the productive chains. The tolerable limit concentration for $\mathrm{Cd}$ and $\mathrm{Pb}$ in honey is 100 and $500 \mathrm{ng} \mathrm{g}^{-1}$, respectively [50] and for $\mathrm{Cr}$ is $100 \mathrm{ngg}^{-1}$ [51]. We can conclude that extracts from aged and fresh propolis meet the technical protocols established by the Brazilian legislation regarding the content of inorganic contaminants in products of animal origin as well as phenolics and flavonoids levels in extracts of propolis.

\section{Conclusions}

This study showed that despite being collected in different periods, propolis samples had a very similar qualitative composition. Samples differed from each other only in relation to their levels of total phenolic content (93.67-149.30) mg/g. Even though aged propolis generally has a different appearance and a drier consistency and, according to beekeepers, this type of propolis is depreciated, data collected in this study indicates that aged propolis still has significant radical scavenging and good antimicrobial activities. These results therefore suggest that aged propolis should not be discarded. Toxic metals $(\mathrm{Pb}, \mathrm{Cr}$, and $\mathrm{Cd})$ were not detected in propolis extracts.

\section{Conflict of Interests}

The authors report no conflict of interests. The authors are alone responsible for the content and writing of the paper.

\section{Acknowledgments}

The study had financial support by Financiadora de Estudos e projetos (FINEP), Conselho Nacional de Desenvolvimento
Científico e Tecnológico (CNPq), Fundação de Amparo à Pesquisa do Estado de São Paulo (FAPESP), Fundação Araucária (10908/PPP/2006), and Pró-Reitoria de Pesquisa e Pós-Graduação (PROPESP) e Fundação de Amparo e Desenvolvimento da Pesquisa (FADESP). Scholarships were provided from Coordenação de Aperfeiçoamento de Pessoal de Nível Superior (CAPES) and CNPq. M.C. Monteiro was recipient of fellowships from $\mathrm{CNPq}$.

\section{References}

[1] F. C. Danert, C. Zampini, R. Ordoñez, L. Maldonado, E. Bedascarrasbure, and M. I. Isla, "Nutritional and functional properties of aqueous and hydroalcoholic extracts from argentinean propolis," Natural Product Communications, vol. 9, no. 2, pp. 167-170, 2014.

[2] A. L. Piccinelli, C. Lotti, L. Campone, O. Cuesta-Rubio, M. C. Fernandez, and L. Rastrelli, "Cuban and Brazilian red propolis: botanical origin and comparative analysis by highperformance liquid chromatography-photodiode array detection/electrospray ionization tandem mass spectrometry," Journal of Agricultural and Food Chemistry, vol. 59, no. 12, pp. 64846491, 2011.

[3] V. Bankova, M. Popova, and B. Trusheva, "Propolis volatile compounds: chemical diversity and biological activity: a review," Chemistry Central Journal, vol. 8, no. 1, article 28, 2014.

[4] V. Bankova, M. Popova, S. Bogdanov, and A.-G. Sabatini, "Chemical composition of European propolis: expected and unexpected results," Zeitschrift fur Naturforschung Section C, vol. 57, no. 5-6, pp. 530-533, 2002.

[5] G. Papotti, D. Bertelli, L. Bortolotti, and M. Plessi, "Chemical and functional characterization of Italian propolis obtained by different harvesting methods," Journal of Agricultural and Food Chemistry, vol. 60, no. 11, pp. 2852-2862, 2012.

[6] A. Kurek-Górecka, A. Rzepecka-Stojko, M. Górecki, J. Stojko, M. Sosada, and G. Swierczek-Zieba, "Structure and antioxidant activity of polyphenols derived from propolis," Molecules, vol. 19, no. 1, pp. 78-101, 2014.

[7] S. Inui, A. Hatano, M. Yoshino et al., "Identification of the phenolic compounds contributing to antibacterial activity in ethanol extracts of Brazilian red propolis," Natural Product Research, vol. 28, no. 16, pp. 1293-1296, 2014.

[8] M. Popova, R. Dimitrova, H. T. Al-Lawati, I. Tsvetkova, H. Najdenski, and V. Bankova, "Omani propolis: chemical profiling, antibacterial activity and new propolis plant sources," Chemistry Central Journal, vol. 7, no. 1, article 158, 2013.

[9] G. Sartori, A. P. Pesarico, S. Pinton et al., "Protective effect of brown Brazilian propolis against acute vaginal lesions caused by herpes simplex virus type 2 in mice: involvement of antioxidant and anti-inflammatory mechanisms," Cell Biochemistry and Function, vol. 30, no. 1, pp. 1-10, 2012.

[10] R. D. Vargas-Sánchez, G. R. Torrescano-Urrutia, E. Acedo-Félix et al., "Antioxidant and antimicrobial activity of commercial propolis extract in beef patties," Journal of Food Science, vol. 79, no. 8, pp. C1499-C1504, 2014.

[11] S. Khacha-ananda, K. Tragoolpua, P. Chantawannakul, and Y. Tragoolpua, "Antioxidant and anti-cancer cell proliferation activity of propolis extracts from two extraction methods," Asian Pacific Journal of Cancer Prevention, vol. 14, no. 11, pp. 6991-6995, 2013. 
[12] K. Wang, J. Zhang, S. Ping et al., "Anti-inflammatory effects of ethanol extracts of Chinese propolis and buds from poplar," Journal of Ethnopharmacology, vol. 155, no. 1, pp. 300-311, 2014.

[13] E. Szliszka, A. Z. Kucharska, A. Sokół-Łętowska, A. Mertas, Z. P. Czuba, and W. Król, "Chemical composition and antiinflammatory effect of ethanolic extract of Brazilian green propolis on activated J774A.1 macrophages," Evidence-Based Complementary and Alternative Medicine, vol. 2013, Article ID 976415, 13 pages, 2013.

[14] H. Xuan, Z. Li, H. Yan et al., "Antitumor activity of Chinese propolis in human breast cancer MCF-7 and MDAMB-231 cells," Evidence-Based Complementary and Alternative Medicine, vol. 2014, Article ID 280120, 11 pages, 2014.

[15] L. Buriol, D. Finger, E. M. Schmidt et al., "Chemical composition and biological activity of oil propolis extract: an alternative to ethanolic extract," Quimica Nova, vol. 32, no. 2, pp. 296-302, 2009.

[16] A. A. Carvalho, D. Finger, C. S. MacHado et al., "In vivo antitumoural activity and composition of an oil extract of Brazilian propolis," Food Chemistry, vol. 126, no. 3, pp. 12391245, 2011.

[17] S. P. Tyagi, D. J. Sinha, P. Garg, U. P. Singh, C. C. Mishra, and R. Nagpal, "Comparison of antimicrobial efficacy of propolis, Morinda citrifolia, Azadirachta indica (Neem) and 5\% sodium hypochlorite on Candida albicans biofilm formed on tooth substrate: an in-vitro study," Journal of Conservative Dentistry, vol. 16, no. 6, pp. 532-535, 2013.

[18] D. Finger, C. S. Machado, Y. R. Torres et al., "Antifungal bioassay-guided fractionation of an oil extract of propolis," Journal of Food Quality, vol. 36, no. 5, pp. 291-301, 2013.

[19] A. C. H. F. Sawaya, D. M. Tomazela, I. B. S. Cunha et al., "Electrospray ionization mass spectrometry fingerprinting of propolis," Analyst, vol. 129, no. 8, pp. 739-744, 2004.

[20] O. Folin and V. Ciocalteau, "On tyrosine and tryptophane determinations in proteins," Journal of Biological Chemistry, vol. 73, pp. 627-650, 1927.

[21] R. G. Woisky and A. Salatino, "Analysis of propolis: some parameters and procedures for chemical quality control," Journal of Apicultural Research, vol. 37, no. 2, pp. 99-105, 1998.

[22] CLSI, "Methods for dilution antimicrobial susceptibility tests for bacteria that grow aerobically; Approved standard-ninth edition," Document M07-A9, Clinical and Laboratory Standards Institute (CLSI), Wayne, Pa, USA, 2012.

[23] M. J. Q. F. Alves, F. F. Mesquita, M. Sakaguti, and A. C. Tardivo, "Hypocholesterolemic effect of propolis' caffeic acids," Revista Brasileira de Plantas Medicinais, vol. 10, no. 1, pp. 100-105, 2008.

[24] A. U. de Quadros, D. Bini, P. A. T. Pereira, E. G. Moroni, and M. C. Monteiro, "Antifungal activity of some cyclooxygenase inhibitors on Candida albicans: PGE2-dependent mechanism," Folia Microbiologica, vol. 56, no. 4, pp. 349-352, 2011.

[25] J. M. Sforcin, A. Fernandes Jr., C. A. M. Lopes, V. Bankova, and S. R. C. Funari, "Seasonal effect on Brazilian propolis antibacterial activity," Journal of Ethnopharmacology, vol. 73, no. 1-2, pp. 243-249, 2000.

[26] M. C. Marcucci and V. Bankova, "Chemical composition, plant origin and biological activity of Brazilian propolis," Current Topics in Phytochemistry, vol. 2, pp. 115-123, 1999.

[27] C. C. Fernandes-Silva, A. Salatino, M. L. F. Salatino, E. D. H. Breyer, and G. Negri, "Chemical profiling of six samples of Brazilian propolis,” Química Nova, vol. 36, no. 2, pp. 237-240, 2013.
[28] Y. K. Park, J. F. Paredes-Guzman, C. L. Aguiar, S. M. Alencar, and F. Y. Fujiwara, "Chemical constituents in Baccharis dracunculifolia as the main botanical origin of southeastern Brazilian propolis," Journal of Agricultural and Food Chemistry, vol. 52, no. 5, pp. 1100-1103, 2004.

[29] L. M. C. Simões-Ambrosio, L. E. Gregório, J. P. B. Sousa et al., "The role of seasonality on the inhibitory effect of Brazilian green propolis on the oxidative metabolism of neutrophils," Fitoterapia, vol. 81, no. 8, pp. 1102-1108, 2010.

[30] É. W. Teixeira, D. Message, G. Negri, A. Salatino, and P. C. Stringheta, "Seasonal variation, chemical composition and antioxidant activity of brazilian propolis samples," EvidenceBased Complementary and Alternative Medicine, vol. 7, no. 3, pp. 307-315, 2010.

[31] J. M. Sforcin, R. Kaneno, and S. R. C. Funari, "Absence of seasonal effect on the immunomodulatory action of Brazilian propolis on natural killer activity," Journal of Venomous Animals and Toxins, vol. 8, no. 1, pp. 19-29, 2002.

[32] A. Salatino, É. W. Teixeira, G. Negri, and D. Message, "Origin and chemical variation of Brazilian propolis," Evidence-Based Complementary and Alternative Medicine, vol. 2, no. 1, pp. 3338, 2005.

[33] A. A. Righi, G. Negri, and A. Salatino, "Comparative chemistry of propolis from eight brazilian localities," Evidence-Based Complementary and Alternative Medicine, vol. 2013, Article ID 267878, 14 pages, 2013.

[34] V. Bankova, "Recent trends and important developments in propolis research," Evidence-based Complementary and Alternative Medicine, vol. 2, no. 1, pp. 29-32, 2005.

[35] G. Papotti, D. Bertelli, M. Plessi, and M. C. Rossi, "Use of HRNMR to classify propolis obtained using different harvesting methods," International Journal of Food Science and Technology, vol. 45, no. 8, pp. 1610-1618, 2010.

[36] J. K. Bastos, J. P. B. de Sousa, M. F. Leite et al., "Seasonality role on the phenolics from cultivated baccharis dracunculifolia," Evidence-Based Complementary and Alternative Medicine, vol. 2011, Article ID 464289, 8 pages, 2011.

[37] J. S. Reis, G. B. Oliveira, M. C. Monteiro et al., "Antidepressantand anxiolytic-like activities of an oil extract of propolis in rats," Phytomedicine, vol. 21, no. 11, pp. 1466-1472, 2014.

[38] N. S. S. Guimarães, J. C. Mello, J. S. Paiva et al., "Baccharis dracunculifolia, the main source of green propolis, exhibits potent antioxidant activity and prevents oxidative mitochondrial damage," Food and Chemical Toxicology, vol. 50, no. 3-4, pp. 1091-1097, 2012.

[39] A. H. Banskota, Y. Tezuka, and S. Kadota, "Recent progress in pharmacological research of propolis," Phytotherapy Research, vol. 15, no. 7, pp. 561-571, 2001.

[40] J. M. Grange and R. W. Davey, "Antibacterial properties of propolis (bee glue)," Journal of the Royal Society of Medicine, vol. 83, no. 3, pp. 159-160, 1990.

[41] K. Bosio, C. Avanzini, A. D’Avolio, O. Ozino, and D. Savoia, “In vitro activity of propolis against Streptococcus pyogenes," Letters in Applied Microbiology, vol. 31, no. 2, pp. 174-177, 2000.

[42] A. Fernandes, E. C. D. Balestrin, and M. L. R. S. Cunha, "Anti-Staphylococcus aureus activity of bee propolis extracts prepared with different ethanol concentrations," Revista de Ciências Farmacêuticas, vol. 24, no. 2, pp. 147-152, 2003.

[43] M. Popova, V. Bankova, I. Tsvetkova, and A. Kujumgiev, "Comparative study of the biological activity of propolis from different geographic origin: a statistical approach," Macedonian Pharmaceutical Bulletin, vol. 50, pp. 9-14, 2004. 
[44] G. A. Burdock, "Review of the biological properties and toxicity of bee propolis (propolis)," Food and Chemical Toxicology, vol. 36, no. 4 , pp. 347-363, 1998.

[45] O. K. Mirzoeva, R. N. Grishanin, and P. C. Calder, "Antimicrobial action of propolis and some of its components: the effects on growth, membrane potential and motility of bacteria," Microbiological Research, vol. 152, no. 3, pp. 239-246, 1997.

[46] T. P. T. Cushnie and A. J. Lamb, "Detection of galangin-induced cytoplasmic membrane damage in Staphylococcus aureus by measuring potassium loss," Journal of Ethnopharmacology, vol. 101, no. 1-3, pp. 243-248, 2005.

[47] T. P. T. Cushnie, V. E. S. Hamilton, D. G. Chapman, P. W. Taylor, and A. J. Lamb, "Aggregation of Staphylococcus aureus following treatment with the antibacterial flavonol galangin," Journal of Applied Microbiology, vol. 103, no. 5, pp. 1562-1567, 2007.

[48] D. Finger, I. K. Filho, Y. R. Torres, and S. P. Quináia, "Propolis as an indicator of environmental contamination by metals," Bulletin of Environmental Contamination and Toxicology, vol. 92, no. 3, pp. 259-264, 2014.

[49] Mapa, Ministry of Agriculture, and Livestock and Supply (Ministério da Agricultura e do Abastecimento), "Instrução Normativa n3,19 de janeiro de 2001," http://www .apacame.org.br/mensagemdoce/60/normas.htm.

[50] Mapa, Ministry of Agriculture, Livestock, and Supply, "Instruction No. 17 of 29 May 2013. Control program of residues and contaminants in honey-PNCRC/2013," IOP Publishing Physics Web, http://www.agricultura.gov.br, (Portuguese).

[51] ANVISA, "Resolução RDC n8 42, de 29 de agosto de 2013. Regulamento Técnico Mercosul sobre Limites Máximos de Contaminantes Inorgânicos em Alimentos," 2014 (Portuguese), http://www.agricultura.gov.br. 

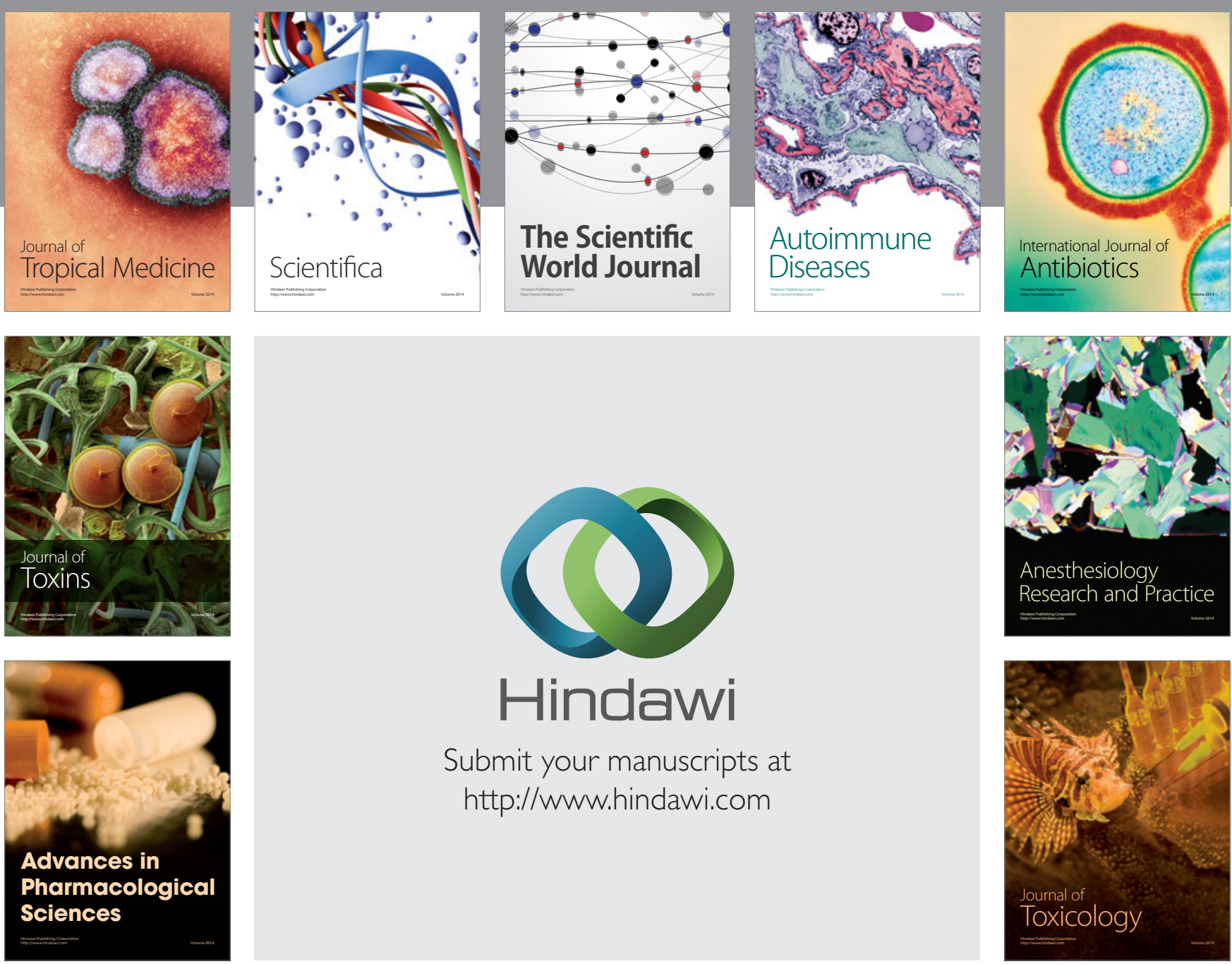

\section{Hindawi}

Submit your manuscripts at

http://www.hindawi.com
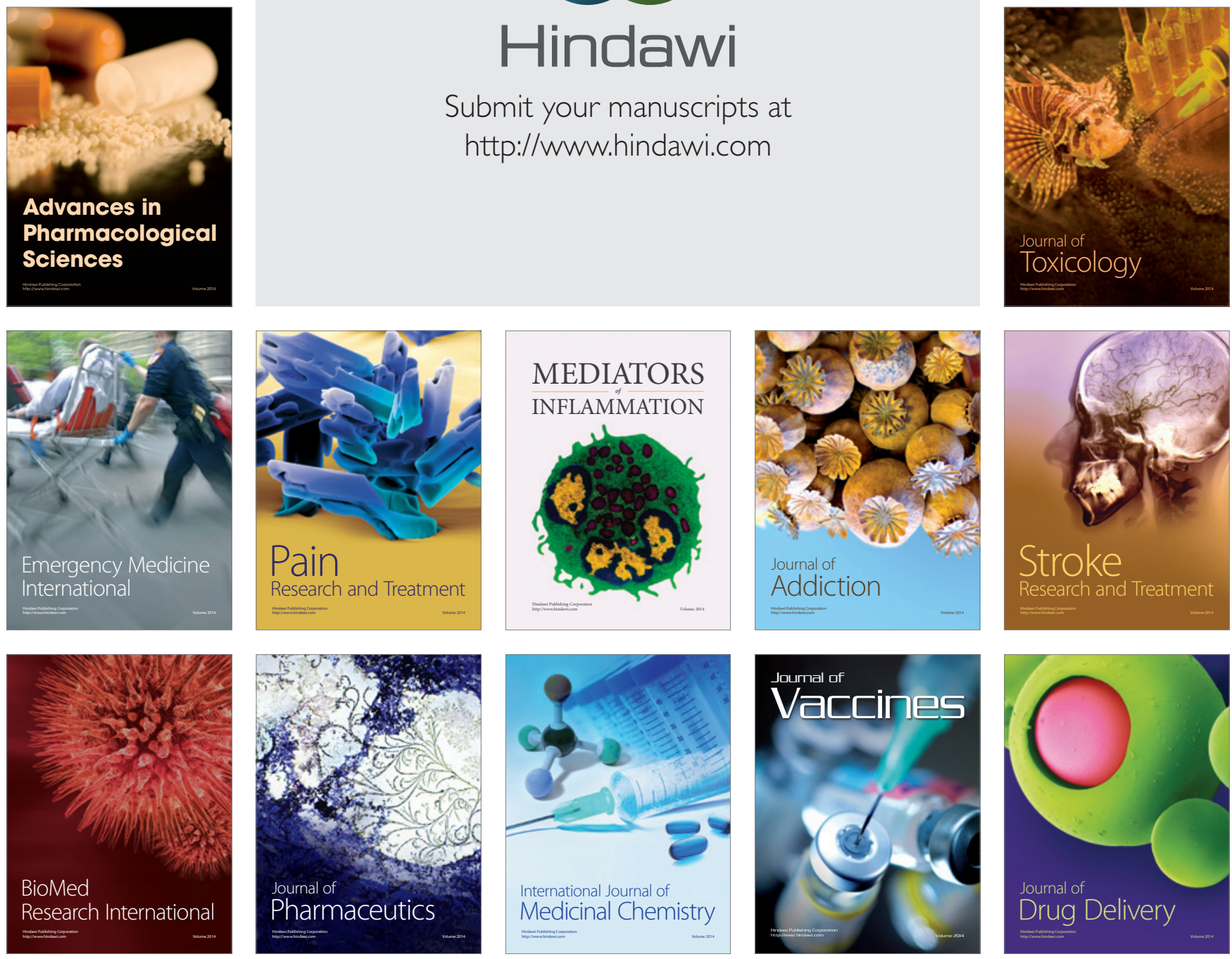